\title{
Zero Tolerance and Violence Prevention Strategies
}

\author{
Sirous Tabrizi \\ Western University, Canada
}

\begin{abstract}
In recent history, a number of incidents have occurred at schools that reduce the quality of education and negatively affect the surrounding community. Some of these are obvious, such as fires, school shootings, and student suicides. Others can be more subtle, such as harassment and prejudice. Regardless of how explicit such incidents may be, there is a need for policies and approaches that increase the safety of students, teachers, and other members of the school community. This paper will briefly examine and discuss three examples of safe school and zero tolerance policies in different contexts, such as bullying. Although zero tolerance policies seem to be supported by multiple levels of education administration, they may not effectively improve the educational environment. This paper will end with a number of recommendations that could be applied to each example case for improving its educational environment.
\end{abstract}

\section{Introduction}

A positive educational environment is a necessity for an effective, motivating, and enjoyable learning experience. Without such an environment, it can be very difficult and at times dangerous for students to learn. As such, the educational environment of any educational institution should be a positive one. An educational environment is the environment in which one learns or teaches. However, the quality of this environment is more about the personal relationships that exist within a school than the act of teaching itself. When all of these relationships involve mutual respect, acceptance, and inclusion then a positive educational environment can result. For example, a classroom is an educational environment in which there are two types of relationships: student-tostudent, and teacher-to student (or student-toteacher). Regardless of a teacher's capacity to impart material to students, a positive educational environment results when these relationships are positive. A number of criteria can be identified that are indicative of a positive environment, such as: feeling safe, comfortable, and accepted in the environment; bullying is strongly discouraged, victims can easily find support, and victims feel comfortable reporting and discussing the incident; and improvement of learning is encouraged and supported. All participants are involved in creating and maintaining a positive educational environment. This includes teachers, students, staff and administrators, volunteers, and parents. Although efforts to create such an environment in a specific school can be performed, more consistent and systematic effort is required if one wants to create positive educational environments in all schools across a country. Safe school policies at a national or provincial level of government are one method of doing this.

Two aspects of safe school policies will be examined in this paper: codes of conduct and zero tolerance. Within safe school policies, a code of conduct can be included as a means for creating a positive educational environment. Should all participants of an educational environment follow a well written code of conduct, a positive educational environment should result. As such, if there are members of the environment who still feel unsafe or uncomfortable, then either too few people are following the code of conduct or the code itself is insufficient. How administrators react to students who do not follow the code of conduct is another aspect of safe school policies. A recent and controversial approach is that of zero tolerance. This approach requires all offenders to be punished uniformly, where students who break the code of conduct are suspended or expelled without consideration for the reasons behind such a breach [15]. To better understand these aspects of safe school policies, the remainder of this paper is divided as follows. In the next section, a brief background discussion of zero tolerance is provided. Following that, the policies of three locations will be critically investigated. Then, a comparative discussion of these locations will be conducted. Finally, the paper will end with some suggestions and insights for general safe school policies to be used in other countries.

\section{Zero tolerance}

According to Winton [20], increasing public perception of schools as unsafe in Canada and the United States has resulted in further attention towards safe school policies. In the United States, zero tolerance as part of safe school policies was adopted with the federal government's War on Drugs in the 1980s [9]. This was expanded to include zero tolerance towards guns and violence in 1994, when Congress passed the Gun Free School Act. By 1999, 
$87 \%$ of US schools had adopted zero tolerance policies for drugs [9].

In general though, a zero tolerance approach can be directed toward any behavior that is contrary to an established code of conduct. For instance, drug use, alcohol use, selling drugs, carrying weapons, sexual harassment, and physical assault are all frequently considered unacceptable behaviors. More recently, school systems have adopted a zero tolerance approach toward bullying as well, with cyber bullying being the most recent issue for administrators to consider. The response to students engaging in such behavior, regardless of the circumstances, is some kind of punishment. Most frequently, the punishment includes suspension with eventual expulsion or outright expulsion. As a result, the students that remain should be in a safer environment, one which only includes those students who abide by the code of conduct. In addition, the hope is that future misbehaviors will decrease as a result of such harsh responses.

However, there is little evidence that a zero tolerance approach improves school safety or deters future misbehaviors [15]. Instead, there is considerable evidence that, as a result of a zero tolerance approach, students who become punished or excluded from school suffer long-term consequences [15]. Such consequences include trouble re-entering school, poor relationships with teachers, academic difficulties, and a growing negative attitude toward school and the adults who are part of the school system [1]. There is also considerable evidence that zero tolerance policies disproportionately affect racial minority students, students with special needs, poor students, and students who are academically struggling regardless of other criteria [2].

Due to such criticism, zero tolerance is losing its popularity. Critics instead suggest that zero tolerance should be used only in exceptional cases, rather than as the primary, typical, or necessary response [20]. Thus, zero tolerance should be the last stage in a series of responses; early preventative programs should be first response, followed by on-going support and interventions, and a range of disciplinary actions to address misbehavior with zero tolerance in this case only when absolutely necessary. Some preventative programs have even been suggested and their effectiveness investigated. These programs include mentoring and tutoring programs, peer mediation, conflict resolution programs, leadership opportunities for students, review of student expectations, work assignments with a learning component, and voluntary community service [15].

\section{Policy case studies}

In this section there will be a brief discussion of safe school policies three locations: Canada, the United States, and Iran. Each case includes an example of a code of conduct as well as their zero tolerance approach. A comparison of these cases will occur in Section 4.

\subsection{Canada}

The Ontario legislature approved a Safe School Act in 2001 that dramatically increased penalties for all forms of harassment. This ensured that there was no focus on the specifics of homophobic violence, and little in the way of change in practice [12]. The teachers in public schools have been protected against discrimination based on sexual orientation for years, and by the end of the 1990s "no denial of benefits to same sex partners could withstand constitutional scrutiny" [13: 231-232]. Also, several provincial unions have taken up sexual diversity issues. The national LGBT rights group Egale has developed a network of educators, even though its small staff and broad mandate allowed for the allocation of no significant resources to the network [12].

Furthermore, formal character education is becoming more common in schools in Canada (as well as England and the United States) where character education refers to the intentional effort by educators to teach values to students. These have been intensified in response to concerns about moral decline, school safety, social cohesion, civic engagement, and academic achievement [19]. For instance, Bill 212 repeals and replaces sections 306 to 311 of the Canadian Education Act in an attempt to improve progressive discipline and school safety. If a pupil engages in an activity set out in new section 306, a principal may suspend the pupil for up to 20 days. The list of activities mirrors the list in old section 306, with the addition of bullying. On suspending a pupil, the principal will be required to assign him or her to a program for suspended pupils provided by the board.

The Code of Conduct in Ontario can be assessed by looking at its fundamental tenets. As stated by the Ontario Ministry of education [see 10], the fundamental tenets of the Code of Conduct in Ontario are: everyone has a responsibility to promote a safe environment; everyone should be aware of their rights; everyone should accept responsibility for protecting their rights and the rights of others; responsible citizenship involves taking part in the civic life of the school; all members of the school community are to be treated with respect and dignity; everyone has a responsibility to resolve conflicts in a way that is civil and respectful; and, everyone is expected to resolve conflicts without using violence. 
One can also examine the roles and responsibilities of principals, teachers and school staff, students, parents, and community partners and police. Since the Code of Conduct applies to all of these components it is useful to investigate each one. The roles and responsibilities of school boards include: developing policies that set out how their schools will implement and enforce the provincial code of conduct; seeking input from outside sources; reviewing policies regularly with students, staff, parents, volunteers and the community; clearly communicating the provincial code of conduct to all members of the community; intervening and responding to all violations of the Code of Conduct; and, providing opportunities for all staff to gain the knowledge, skills and attitudes they need to develop and maintain academic excellence and safe learning and teaching environments [10].

The roles and responsibilities of principals include: demonstrating care for the school community and commitment to academic excellence in a safe teaching and learning environment; holding everyone under their authority responsible for their behavior and actions; empowering students to be positive leaders in their school and community; and, communicating regularly and meaningfully with all members of their school community [10]. The roles and responsibilities of teachers and school staff include: helping students work to their full potential and develop their self-worth; empowering students to be positive leaders; communicating regularly with parents on important issues; maintaining consistent standards of behavior for all students; showing respect for all students, staff, parents, volunteers and members of the school community; and, preparing students for the full responsibilities of citizenship.

The roles and responsibilities of students include: coming to school prepared and ready to learn; showing respect for themselves and others; refraining from bringing anything to school that may put the safety of others at risk; and, following the established rules and taking responsibility for his/her own actions [10]. The roles and responsibilities of parents include: showing an active interest in their child's education; communicating regularly with the school; making sure their child is neat, properly dressed and prepared for school; ensuring that their child attends school regularly and on time; informing the school promptly about their child's absence or late arrival; becoming familiar with the provincial code of conduct, the board's code of conduct and school rules; encouraging and helping their child follow the rules of behavior; and, helping school staff deal with disciplinary issues involving their child. And finally, the roles and responsibilities of community partners and police include: forming partnerships with community agencies and members of the community; providing resources to school boards; supporting and respecting the rules of their local schools; and, investigating incidents in accordance with the protocol developed with the local school board [10].

\subsection{The United States of America}

The Student Support Service (SSS) in the New York State Education Department (NYSED) has several programs about Safe Schools Against Violence in Education (SAVE). The NYSED promotes safe learning environments with the following: additional school safety resources, codes of conduct, programs to reduce child abuse in an educational setting, finger printing regulation, and violence prevention \& intervention programs. Zero tolerance policies were adopted from the military, becoming a model for K-12 public education policies [13].

Moreover, a number of intervention models have been developed to encourage a safe education experience for and promote resilience among LGBTQ students and educators [14]. One example of such models includes the special interest residential houses of the University of Massachusetts at Amherst. Furthermore, in 2002 the U.S. Department of Education and the U.S. Secret Service published the findings of the Safe School Initiative and published a guide for using threat assessment in school to help create a safe school climate [see 3]. This was in addition to the fundamental principles and steps of the threat assessment program. The report suggested that: schools should have clear policies about how to respond to potentially threatening situations and how to conduct a threat assessment; schools should establish a threat assessment team trained to respond to potentially threatening situations; and schools should build relationships between individuals and organizations to create policies and procedures for collaboration and cooperation [3].

According to Hughes [6], the number of students identified with behavioral problems is a significant proportion of the youth who receive special education services in the United States. The 1997 reauthorization of the Individuals with Disabilities Education Act, for example, focused almost entirely on discipline requirements and other issues surrounding aggressive and misbehaving students [6]. Many schools and school districts have implemented protective policies for LGBTQ students regardless of whether statewide laws exist regarding harassment of all students. For instance, the 10 largest school district policies specifically include language about gender identity or expression. There is some evidence suggesting that such policies can have a positive effect on school experience for LGBTQ students.

For example, Kosciw and Diaz [8] found that schools with harassment policies had students who 
were less likely to hear homophobic remarks or verbal harassment due to sexual orientation. In addition, students who had been harassed in school were more likely to report the harassment when their school had a comprehensive policy than in schools with no policy or only a generic policy $(25 \%, 16 \%$ and $12 \%$, respectively). Thus, these policies may serve to instill greater confidence in students that their teachers and administrators will address any incidents that occur [7]. Further, teachers may be more likely to act on behalf of students who are being harassed if there is a policy in effect [7]. Pursuant to the No Child Left Behind Act of 2001, when a student becomes the victim of a violent criminal offense while in or on the grounds of the public elementary or secondary school he or she attends, his or her parents must be notified by the local educational agency of their right to transfer the child to a safe public school within the district.

The Code of Conduct in New York State can be addressed by looking at its fundamental tenets. These include: first, school property includes in or within any structure, building, playground, athletic playing field, parking lot or land contained within the real property boundary line of a public elementary or secondary school; or in or on a school bus, as defined in section one hundred forty-two of the vehicle and traffic law; and a school function shall mean a school-sponsored extra-curricular event or activity [see 17].

Second, the board of education or the trustees, of every school district within the state such as disciplinary measures to be taken in incidents involving the possession or use of illegal substances or weapons, the use of physical force, vandalism, violation of another student's civil rights and threats of violence; provisions regarding conduct, dress and language deemed appropriate and acceptable on school property; provisions ensuring such code and the enforcement thereof are in compliance with state and federal laws relating to students with disabilities; procedures by which violations are reported, determined, discipline measures imposed and discipline measures carried out; provisions setting forth the procedures by which local law enforcement agencies shall be notified of code violations which constitute a crime; circumstances under and procedures by which referral to appropriate human service agencies shall be made; provisions setting forth the circumstances under and procedures by which a complaint in criminal court; a minimum suspension period, for students who repeatedly are substantially disruptive of the educational process or substantially interfere with the teacher's authority over the classroom.

Third, the district code of conduct shall be developed in collaboration with administrator, teacher, student, and parent organization. Fourth, the board of education, head of government or other governing body shall provide copies of a summary of the code of conduct in the beginning of the school year for all students and shall make copies of the code available to persons in parental relation to students at the beginning of each school year. Finally, each state or district shall file a copy of its codes of conduct with the official and all revisions to such code shall be filed with the commissioner no later than thirty days after their adoption; the board of education, chancellor or other governing body shall annually review and update the district's codes of conduct if necessary, taking into consideration the effectiveness of code provisions and the fairness and consistency of its administration.

\subsection{Iran}

The third country is Iran, which is in Asia (Middle East). In Iran, the Islamic religion and Islamic government have developed a masculinity approach over the last thirty years. Zero tolerance with severe punishment is especially visible in rural areas. In the Iranian education system, as in other countries, all responsibility is divided between different groups. We can also examine the roles and responsibilities of principals, teachers and school staff, students, parents, and community partners and police [see 16]. The roles and responsibilities of school boards include: manage Hejab especially between female students; all students have to wear Hejab before and after school; developing policies that set out how their schools will implement and enforce the provincial code of conduct; reviewing policies regularly with students, staff, parents, volunteers and the community; clearly communicating the provincial code of conduct to all members of the community; if students make a problem their parents must intervening and responding to all violations of the Code of Conduct; all students have to do religious practices in schools; if a student wants to distract other students for a first punishment he or she will deprive from first shift and in the second step he or she will be expelled from school.

Furthermore, the Islamic Republic of Iran has undergone many changes in the past few decades, shifting from a focus on modernization to a traditional Muslim society. These changes have impacted the education system, which is a fundamental part of the country. The biggest change is that all aspects of school and curriculum have a religious component [4]. The changes in Iran have been mirrored in the educational system, and provide an interesting way to study the ideological shift in Iran's political scene.

LGBTQ Iranians live in various circumstances, social classes, and geographies. Unfortunately, most of the research about LGBTQ people in Iran focuses exclusively on the capital city of Teheran, and often 
on the northern, most affluent area of the city. Homosexuality is considered a crime punishable by death, such that being a gay or lesbian in Iran is quite dangerous. The Persian Gay and Lesbian Organization (PGLO) in Canada hopes to reach LGBTQ individuals throughout Iran, not just in the largest cities. Iranian LGBTQ people suffer from both the Islamic government's law and persecution in other aspects of their lives [11]. If their sexual orientation or gender identity is discovered, LGBTQ people are often abandoned by their families and are fired from their employment. Suicide is not uncommon when this happens.

\section{Comparative discussion}

Author Schools should function to prevent violence but also to address violence in collaboration with police forces and other first responders. According to Wilson and Kolander [18], the following five points can serve as a general outline of the components of a school safety plan. First, convene a safe school planning team for resolving school violence problems. Second, conduct an annual school site assessment. Third, develop strategies and implement violence prevention program to address school safety concerns. Fourth, increase the role of family and finally, teach students how to control violence. Both NY State and Ontario have similar social, economic, and demographic situations. One of the most notable similarities is the percentage of the population enrolled in university. However, education in Canada is a matter of provincial jurisdiction, so it is difficult to make any sweeping generalizations about the whole system. In Iran, not only are the social and economic issues different than Canada and the USA, but the education system is also different. All decisions are made centrally in the capital and apply to the provinces.

Safe school policies regarding code of conduct has the same function in Ontario and New York; in both places, and even in Iran, zero tolerance policies have been adopted in various school and other education venues. The main reason for a zero tolerance approach with prevention policies is to control drug and alcohol use, and selling drugs; carrying weapons, sexual harassment or physical assault, violence, and any form of bullying behavior. Legislation in Ontario and New York focus on school conduct and discipline issues, such as discipline in schools, suspension and expulsion, and parental notice concerning student suspensions. Generally speaking, legislation in the Iranian education system forbids corporal punishment at any level of schooling. However, in most schools, especially rural schools, corporal punishment remains common. In addition, Mehran [in 6] writes that the inappropriate behavior of teachers remains a bitter reality in rural and nomadic schools. Physical punishment, psychological degradation, imposition of too many restrictions, excessive discipline, and creating an atmosphere of fear and anxiety, especially by younger, inexperienced teachers, is a problem for both boys and girls. Parents, however, reported that their daughters begin to hate their school and their teacher immediately upon encountering any of the above [5].

Neo-conservatism has a strong political presence in the USA, Canada, and Iran. Neo-conservatism promotes traditional values to the extent that it may reject individual rights. Additionally neoconservatism defines national interests to include ideological interests (e.g. the defense of other nations with similar ideologies for geopolitical purposes, proposing to use American economic and military power to bring democracy and freedom to other countries, and so on). Although all three countries here are similar in terms of a neo-conservative approach, developed countries such as the USA and Canada are more inclusive towards other cultures and ideas, whereas Iran is more exclusive and restricted.

Both NY State and Ontario, relying on critical democracy, were successful in establishing some rights for LGBT students and have therefore witnessed a decrease in harassment, bullying, sexism, and assault. On the other hand, Iran has a fundamental problem because all citizens have to obey legislations that are extracted from Islam. Lesbians, Gays, and Bisexuals are not accepted as normal citizens and their punishment is execution for Gays, and lashing for Lesbians. Transsexuals are accepted, assuming they have a sex change. However, any LGBTQ citizen, especially students, has a much more difficult time in Iran than in Canada or the US.

\section{Conclusion}

A safe and effective learning environment is desirable for any educational institution, regardless of its country of origin. As such, policies should be developed that promote and maintain such environments in the school. In developing these policies, it would be beneficial to look at other examples of countries or groups who are trying to create positive environments, so as to gain inspiration for and evaluation of possible strategies. Iran would benefit from a Code of Conduct that involves a greater degree of respect of others, and one that is especially universal in its application. Doing so could help to alleviate some of the prejudice and harassment that members of the LGBT community face in schools. Canada and the United States would benefit from requesting a greater responsibility of parents and family in the growth and discipline of their children. A safer learning 
environment could result from an increased role of the family in managing student behavior, instead of leaving such management entirely in the hands of teachers and staff [18]. This is especially true when one considers the effects of cyber bullying, that is made worse when there is little communication and support between parents and their own children within the home. A safe school environment requires the participation of all members of the community, and unfortunately the roles which individuals play in this community can be overlooked.

In addition, a zero tolerance approach has been attempted and losing much support among parents and educators. While using a zero tolerance approach, the emphasis of a safe school policy becomes focused on ensuring that the immediate environment does not include disruptive students. Students who are struggling or unable to effectively learn in some environment become bored, disconnected, and eventually troublesome and disruptive. These students are then suspended or expelled. As a result, the actual underlying cause of an unsafe school is never addressed. Therefore, any safe school policy should include an approach that aims to assist struggling students with school to prevent them from becoming a problem.

\section{References}

[1] T.M. Brown, "Lost and turned out: Academic, social, and emotional experiences of students excluded from school", Urban Education, vol. 42, no. 5, 2007, pp. 432455 .

[2] Y. Daniel, and K. Bondy, "Safe school and zero tolerance: Policy, program and practice in Ontario", Canadian Journal of Educational Administration and Policy, vol. 70, 2008, retrieved from http://www.umanitoba.ca/publications/cjeap

[3] Fein, R.A., B. Vossekuil, W.S. Pollack, R. Borum, W. Modzeleski, and M. Reddy, Threat Assessment in Schools: A Guide to Managing Threatening Situations and to

Creating Safe School Climates, U.S. Secret Service / U.S. Department of Education, Washington D.C., 2004, retrieved from http://www.ed.gov/admins/lead/safety/threatassessmentgui de.pdf (Access date: 12 March 2013).

[4] L. Fernald, "Iranian education: From modernization to traditionalism”, 2007.

[5] Harber, C., and L. Davies, School Management and Effectiveness in Developing Countries: The PostBureaucratic School, Continuum, New York NY, 1998.

[6] Hughes, L.W. (Ed.), Current issues in school leadership, Lawrence Erlbaum Associates, Mahwah NJ, 2005.

[7] Klein, S.S., B. Richardson, D.A. Grayson, L.H. Fox, C. Kramarae, D.S. Pollard, and C.A. Dwyer, (Eds.),
Handbook for achieving gender equity through education., Lawrence Erlbaum Associates, Mahwah NJ, 2007.

[8] Kosciw, J.G., and E.M. Diaz, The 2005 national school climate survey: The experiences of lesbian, gay, bisexual, and transgender youth in our national's school, Gay Lesbian \& Straight Education Network (GLSEN), New York NY, 2006.

[9] Mosher, C.J., and S. Akins, Drugs and drugs policy, SAGE Publications, Thousand Oaks CA, 2007.

[10] Ontario Ministry of Education, "Code of Conduct", 2008, retrieved from http://www.edu.gov.on.ca/eng/safeschools/code.html (Access date: 8 April 2011).

[11] Parsi, A., "Persian Gay and Lesbian Organization", Encyclopedia of gay, lesbian, bisexual, transgender, and queer culture, 2006, retrieved from http://www.glbtq.com/social-sciences/persian_glo.html (Access date: 8 April 2011).

[12] Rayside, D., Queer Inclusions, Continental Divisions: Public Recognition of Sexual Diversity in Canada and the United States, University of Toronto Press, Toronto ON, 2008.

[13] Reyes, A.H., Discipline, Achievement, and Race: Is Zero Tolerance the Answer, Rowman \& Little field Publishing, Lanham MD, 2006.

[14] Sears, J.T. (Ed.), Youth, education, and sexualities: An international encyclopedia, Greenwood Press, Westport CT, 2005.

[15] R.J. Skiba, C.R. Reynolds, S. Graham, P. Sheras, J.C. Conoley, and E. Garcia-Vazquez, "Are zero tolerance policies effective in the schools? An evidentiary review and recommendations", A Report by the American Psychological Associate Zero Tolerance Task Force, 2006.

[16] Supreme Education Council, School Executive Regulations: Student Disciplinary Regulation, Tehran Iran, 1999.

[17] New York State Education Department (NYSED), "Codes of conduct on school property", retrieved from http://www.p12.nysed.gov/sss/ssae/schoolsafety/save/2801 -CodesofConduct.html (Access date: 8 April 2011).

[18] Wilson, R.W., and C.A. Kolander, Drug Abuse Prevention: A School and Community Partnership (Third Edition), Jones and Bartlett Publishers, Sudbury MA, 2010.

[19] Winton, S., "The appeal(s) of character education threatening times: Caring and critical democratic responses", Comparative Education, vol. 44, no. 3, 2008, pp. 305-316.

[20] Winton, S., "Managing conduct: A comparative policy analysis of safe schools policies in Toronto, Canada and Buffalo, USA", Comparative Education, vol. 47, no. 2, 2011, pp. 247-263. 